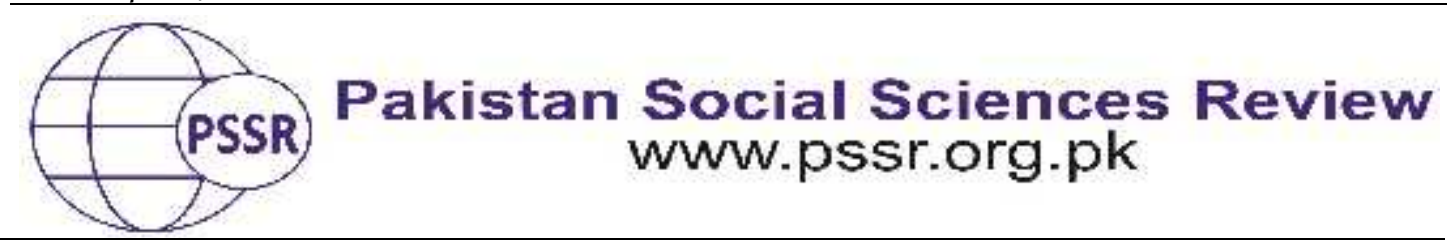

RESEARCH PAPER

\title{
An Investigation into Peace Teaching Practices in Secondary Schools of the Punjab, Pakistan
}

\author{
Naveen Amber* ${ }^{1}$ Dr. Zafar Hayat ${ }^{2}$ Dr. Muhammad Pervaiz ${ }^{3}$
}

1. M. Phil Scholar, Department of Education, University of Sargodha, Punjab, Pakistan

2. Headmaster, Government High School Sangoraka, Sargodha, Punjab, Pakistan

3. Principal, Minhaj ul Quran Public School Chak No. 1, Rakh Dhrema, Sargodha, Punjab, Pakistan

\begin{tabular}{|c|c|}
\hline PAP & I \\
\hline Rece & Presen \\
\hline & pract \\
\hline Acc & The whole proce \\
\hline & phase' of Castro \\
\hline & this \\
\hline Edu & les) \\
\hline Man & \\
\hline Pea & \\
\hline & to \\
\hline & (1) \\
\hline $\begin{array}{l}{ }^{*} \text { Cor } \\
\text { Auth }\end{array}$ & $\begin{array}{l}\text { bal } \\
\text { ity' } \\
\text { ies. }\end{array}$ \\
\hline $\begin{array}{l}\text { nave } \\
6 @ g n\end{array}$ & $\begin{array}{l}\text { tudy is hoped to sensitize the education managers and the } \\
\text { ers to pay special attention towards teaching the ignored } \\
\text { e values. }\end{array}$ \\
\hline
\end{tabular}

\section{Introduction}

Children naturally get influence from their environment (of peace or violence what so ever) and will soon grow into next generation (Balasooriya, 2001). The school environment will decide their patterns of behaviour. Although it is generally believed that more education yields less violent attitudes (Krueger \& Malečková, 2003) however, some highly educated persons have been found involved in terrorist activities (Ali, 2015). Studies found that there may exist a positive correlation between education and violence. It was also found in the context of Middle East clash that getting education may cause terrorist activities or be potentiated by it in different ways. The propensity of an individual to join some terrorist groups may increase if the content supports some political or religious messages. (Atran, 2003; Berrebi, 2007). It must also be considered that education, particularly formal education, puckishly is misused/or be misused to create stereotypes of enmity, 
extreme nationalism and hate(Harber \& Sakade, 2009). Mere education is not the only way to eliminate violence or promote peace; in actual sense nature of education matters (Atran, 2003). Although schools, globally, are considered as the marvellous places for educating peace, yet they may serve as the breeding ground for personal, structural and cultural violence. They may not only facilitate to deteriorate but to incarnate religious, ethnic and social conflicts as well as discriminations over a long period of time (Davies, 2013).

Peace education, through its essentially transformative nature, promotes the culture of peace by cultivating knowledge base, skills, attitudes and values among people (Ardizzone, 2001; D. W. Johnson \& Johnson, 2010; Khalid, 2013; Tanabe, 2014). It creates conditions and systems that actualize nonviolence and justice, and other peace values (Castro \& Galace, 2010). To highlight the urgency of peace, UNESCO observed the very first decade of $21^{\text {st }}$ century (2001-2010) as the 'Decade of Peace and Nonviolence for the Children of the World (Fountain, 1999). It follows that peace education should be placed at core in the education system.

The evident urgency of peace education gives rise to the ultimate question that: are our schools really working for producing a peaceful new generation? To answer this question, Government of Pakistan in 2009, decided to reaffirm its education vision. This reaffirmed vision was adopted after the identification of deficiencies on the basis of a rigorous analysis of previous education policies and their implementation. These deficiencies include the lack of commitment to education and the weak implementation (GOP, 2009). This new education vision incorporated several peace values as:

"Our education system must provide quality education to our children and youth to enable them to realize their individual potential and contribute to the development of society and nation, creating a sense of Pakistani nationhood, the concepts of tolerance, social justice, democracy, their regional and local culture and history based on the basic ideology enunciated in the Constitution of the Islamic Republic of Pakistan."(P-17)

To realize this new vision of education twenty aims and objectives were articulated in National Education Policy 2009 and 2017(GOP, 2017). Almost all the peace values incorporated in Castro \& Galace Model of Peace Education (CGMPE, 2010) were reflected in these objectives. For example, objective $1 \& 2$ of the National Education Policy 2009 stressed upon fulfilling social, political and spiritual needs as well as strengthening the concept of basic ideology enshrined in the Constitution of the Islamic Republic of Pakistan 1973 (Peace value-1: Self-respect). Objective-3 focussed on promoting the desire to create a welfare state (Peace value-11: Social Responsibility). Objective-4 intended to promote sense of respect for each other's faith/religion and cultural/ethnic diversity (Peace value-2; Respect for others). Objective 5 \& 6 emphasized on equality in education opportunities for all the citizens of Pakistan including minorities (Peace value-10: Justice). Objective-7 concentrated on making individuals capable of original thinking as a global citizen (Peace value-6: Global Concern). Objective- 9 accentuated on many peaceable attitudes/values e.g. 
raising commitment of individuals on democratic and moral values; awareness to basic human rights; openness to innovative ideas; and promoting personal responsibility to contribute in productive activities for common good of the society (Peace value-9: Openness and Tolerance, Peace value-11: Social Responsibility and Peace value-8: Cooperation). Objective-15 laid stress on equalizing access to education for boys and girls and the marginalized segments of the society (Peace value-4: Gender Equality, Peace value-5: Compassion). Objective-17 intended to enable the students to honestly earn his/her livelihood and make informed choice in their life (Peace value-7: Ecological Concern, Peace value-12: Positive Vision). Objective-20 focused on reducing disparities across provinces and supporting coordination and sharing of experiences (Peace value-8: Cooperation) (GOP, 2009).

This evident emphasize on peace values in the objectives of National Education Policy 2009 and 2017 could bear fruit only when it would have been implemented in true letter and spirit. It ultimately calls for proper teaching methods and duly trained peace loving teachers to carry out peace education practices. The provision of these pre-requisites may result in producing a peaceable next generation. Unluckily, in the past, education sector was unable to perform at par and serious deficiencies had been reported in materializing the policy guidelines e.g. lack of commitment to education itself by the government and the gap between policy and practice(GOP, 2009, 2017).It obviously necessitates a rigorous study to examine the existing situation of peace education practices.

\section{Material and Methods}

It was a descriptive study. Qualitative survey design was used to execute it. The descriptive studies endeavour to describe, as fully and carefully as possible (Fraenkel, Wallen, \& Hyun, 2012, 2015), the existing state of affairs of the given research problem: what it is (Best \& Kahn, 2006; Cohen, Manion, \& Morrison, 2013). In education settings, a researcher, while conducting a descriptive research, may examine the characteristics (e.g. preferences, attitudes or behaviours etc.) of individuals or groups (e.g. students, teachers and/or administrators) or physical environment (e.g. school etc.) (Fraenkel et al., 2012, 2015). Qualitative investigation is typically embedded in constructivism. Contrary to the positivism, constructivist paradigm is based on the assumption that the individuals, "while seeking to understand the world around them", construct meanings of their experiences (Aree, 2011). These meanings vary with the variation in individuals' experiences and perceptions (Craig, 2005). Constructivists or qualitative researchers heavily rely on the views of the informants about the situation under investigation (Creswell, 2013).

Informants of the study were selected in the following way: firstly, four (4) administrative divisions, out of nine (9) of the Punjab, were taken randomly. Secondly, from each selected division, one district was chosen randomly (Lahore, Mandi Baha ud Din, Sargodha and Multan). Thirdly, from each district, eight (8) public secondary schools were taken with an equal consideration of rural/urban and male/female schools. Finally, all head teachers of the selected public secondary schools (32) andthe Chief Executive Officers(CEOs) and District Education 
Officers(DEOs) of the selected districts $(4+4=8)$ were included as informants of the study $(32+8=40)$.

A self-developed semi-structured interview schedule was usedto gather information from education managers. It was embedded in twelve (12) peace values (self-respect, respect for others, respect for life/nonviolence, gender equality, compassion, global concern, ecological concern, cooperation, openness and tolerance, justice, social responsibility, and positive vision). These values were taken from 'Affective Phase' of' Schema of Peace Education' developed by Loreta NavarroCastro and Jasmine Nario-Galace from Mirriam College, Quezon City, Philippines in (2010). The model was mentioned in their globally recognised book "Peace Education: A Pathway to a Culture of Peace".

At the outset of the interviews of education managers they were presented a hand-out carrying the model of peace education used in this study. They were briefed about the affective phase of this model being used in the study which involved 12 peace values. These peace values and their subsidiary indicators were also discussed with them. When they were familiar enough with the peace values, they were asked the questions about the peace education practices in the schools. Thematic analysis technique was employed for the qualitative analysis of data collected from the education managers.

\section{Results and Discussion}

Theme-wise findings of the interviews with the education managers is given hereunder:

\section{Theme-1: Self-respect}

The 'self-respect' in this study is referred to 'having sense of 'one's own worth'; 'pride in one's particular social, cultural and family background'; 'sense of power and goodness supportive to bring about positive change' (Navarro-Castro \& Nario-Galace, 2010). These concepts coincide with the idea of 'respect for human dignity' within the value of 'human rights' (GOP, 2017; Vira \& Cordesman, 2011). The article 14 (1), of the Constitution of the Islamic Republic of Pakistan, guaranties that the dignity of man shall be inviolable (GOP, 2012).

Education managers were asked to inform about the teaching-learning practices in secondary schools in connection with the 'self-respect'.In the view of maximum number of education managers $(f=36)$, the peace value 'self-respect' is tried to inculcate in the minds of students. However, they stated that unfortunately it is not taught in its real sense. Talking about the sub-themes, they opined that the secondary schools do not properly develop self-confidence in their students so that they may rely on their potential and capabilities. However, some of them $(f=12$, Head teachers) opined that their schools try to enhance 'self-confidence' among their students. For example, one of the head teachers stated: 
"All the students are provided the opportunities to groom the hidden potentials; they are encouraged to come on the stage during 'Bazm-e-Adabb' and perform something of their own choice and sometimes as per their assignment." (Respondent-15)

"Students are involved in several co-curricular activities; they take part in Tilawat صلى الله (Recitation of Holy Quran) competition, Naat (Hymn of Holy Prophet Muhammad (علي وآل وسلم وس (National Songs) and speech competition. They actively participate in different activities on 'Special Days' i.e., Eid Milad-un-Nabi (the birthday of Holy Prophet (1), Pakistan Resolution Day on 23rd March, and Independence Day on 14 August etc. Their active participation in these activities obviously helps them feel pride on their cultural background." (Respondent-40: Head Teacher)

It was obvious from the data that in most of the schools particularly, rural schools, students get negative reinforcement about their social, cultural and family background. Hence, they adversely feel pride on their social, cultural and family background. In the views of majority of the respondents, students are not trained to accept and respect the diversity of cultures and its inevitability $(f=28)$. A few of them $(f=08$, Head teachers) maintained that they make their students aware of positive cultural values and traditions from Islamic History particularly from the life of Holy

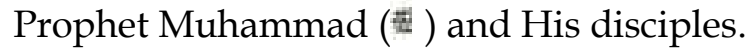

"Teachers merely try to teach the content. They are commonly unaware of national and global issues of modern age. They are notorious of not reading any additional books and seem lagging behind in adopting the standards for 21st century teachers." (Respondents-21: CEO)

Maximum number of respondents $(f=32)$ were found saying that the attribute of 'ethical power' and 'goodness' are not developed among students necessary to make them capable of contributing towards positive change in the society. Although majority of the head teachers affirmed that the peace value of 'self-respect' is not properly taught to students in secondary schools however some of them were found justifying the situation.

"The schools are compelled by the department to enrol maximum number of students with limited facilities and less teaching staff coupled with desirable results in annual examinations. Schools are constrained to focus on results rather than grooming their students. Consequently, the area of teaching them moral values is heavily compromised." (Respondent-27: Head teacher)

\section{Theme-2: Respect for others}

Them-2 (respect for others) operationally, for this study, means 'respecting the worth and dignity of other people including those who have different social, religious, cultural and family backgrounds' (Navarro-Castro \& Nario-Galace, 2010).

The peace value 'respect for others' bears a significant importance all over the world. It is considered vital for peaceful coexistence and it coincides with the concept of "Learning to Live together" disseminated by UNESCO (GOP, 2017) which 
stresses "the development for understanding, consideration and respect others, their beliefs and cultures". Constitution of the Islamic Republic of Pakistan holds Government of Pakistan responsible to take steps to ensure the respect of each other's identities. It states that "The state shall discourage parochial, racial, tribal sectarian and provincial prejudices among the citizens"(GOP, 2012).

Talking about the peace education practices in public secondary schools, majority of the respondents $(f=34$, mostly head teachers) stated that students are taught about 'respect for others' by quoting relevant Ayats (Verses from Holy Quran) and noble examples of high ranked personalities from the Islamic history. The students are directed to wait for their turn while participating in discussion or responding to a question. Moreover, they are advised not to sit on others seats; avoid humiliating other fellows; avoid walking ahead of their teachers; queue up while entering or going out the class and wait for their turn; stand up on the arrival of teachers and at the time of 'National Anthem' and the like. However, most of the education managers $(f=26)$ affirmed that the true spirit for teaching peaceable value of 'Respect for others' is still badly missing.

"There is a dire need to train students to acknowledge the abilities and accomplishments of others. This could best be done, I think, by promoting sportsman spirit among students." (Respondent-37: Head Teacher)

On the other hand, respondent-21 (CEO) presented a counter argument by highlighting another aspect:

"Our so called local cultural beliefs and traditions are highly deep rooted; many of them are allegedly based on centuries old stereotypes. People try to avoid discussing the implications of these negative beliefs. They, including teachers, go with the way the wind blows. Furthermore, it is common culture here to discuss the weaknesses of other people with references to their social, cultural, religious and particularly their family background, and we cannot exclude our teachers too."

\section{Theme-3: Respect for Life/Non-violence}

For the present study, 'non-violence' means 'valuing of human life'; 'refusal to respond a conflict situation with violence'; and preference for using non-violent ways in place of force or weapon to settle the disputes' (Navarro-Castro \& NarioGalace, 2010).

It is clear that maximum number of education managers $(f=34)$ established that the students are educated about 'respect for life/nonviolence' in various ways. Respondent-38 (Head teacher) said:

"Government of the Punjab is taking keen interest to deal with security issues. Boundary walls of schools have been constructed and barbed wire has been installed. Government has issued certain directions to assure the security of students. For example, 
emergency numbers have been displayed in schools for any kind of emergency. All these measures indirectly convey a message to students that how much worthwhile the human life is. Moreover, Rescue officials from '1122' emergency service and traffic police visit our school and educate our students about the safety of their own and other's life."

"Corporal punishment is prohibited in schools. We remain vigilant and try our best to stop any type of violence in the school. Students are not allowed to act violently in the school premises." (Respondent-17: Head Teacher)

"During regular classroom teaching, teachers refer Islamic commandments about the importance of saving and protecting human life. They put the examples of Holy Prophet ( how he emphasized the caring of animals, birds and even insects; how he motivated His followers not to harm any living being.... and on special occasions like 'Eid Milad-un-Nabi', this message is conveyed more strongly to students."(Respondent-29: Head Teacher)

On the other hand, some of them (Respondent-2 \& 22: DEOs, 16: Head Teacher, and 31: CEO) showed their serious concerns that the students are needed to be trained practically how to react 'non-violently' in a conflict situation. They should be acquainted with the non-violent processes for resolving the disputes and capable of using these processes in place of physical force.

\section{Theme-4: Gender Equality}

Here operationally, the theme of 'gender equality' is composed of four subthemes. It involves 'valuing the right of women to enjoy equal opportunities as of men; to make them free from all kinds of abuse, exploitation and violence' (NavarroCastro \& Nario-Galace, 2010). Article 34 of the Constitution of Pakistan explicitly speaks that "steps shall be taken to ensure full participation of women in all the spheres ofnational life" (GOP, 2012).Gender equality is one of the key global issues and is understood as an inevitable peace value (Emah, Akpanumoh, Akpan, \& Jude, 2008; GOP, 2017; Ty, 2011).

Maximum number of education managers $(f=32)$ viewed that no appropriate teaching practices are carried out in secondary schools to promote the sense of "Gender Equality particularly in boys' secondary schools.

"It has never been a point of interest for male teachers in secondary schools" (Respondent-12: DEO)

"It is just confined to discuss in speeches on 'Special Days' or while classroom teaching wherever included in the text" (Respondent-7, 15, 33: male Head Teachers).

"While teaching Islamic Studies teachers strive to acquaint their students with the concept of 'Gender Equality' and mention some examples from the life of Holy Prophet ( صلى صل how he awarded the basic human rights to women first time ever in human history." (Respondent-8, 24: Female Head Teacher) 
A reasonable number of female head teachers ( $\mathrm{f}=12$ out of 16$)$ opined that they make their girls students aware of their globally accepted basic human rights comparable of men. They blamed boys' school teachers that they do not make any effort to educate their students about equality of basic human rights for both male and female; and that the women should be freed from any kind of abuse, exploitation and violence.

"Ours is a man dominated society and women are usually exploited in terms of their basic human rights specifically. The schools are regarded as the mirror of any society and the results are obvious." (Respondent-16: female Head Teacher)

Respondent-28 (a female head teacher) argued that the issue of 'gender equality' can be taken as a typical example of the disastrous gap between theory and practice. "We believe in Islamic teachings but are not ready to give equal basic human rights to women, what a pity! And yet are not seen even willing to educate our next generation to do that" she uttered.

\section{Theme-5: Compassion}

Operationally, the concept of 'compassion' involves 'sensitivity to the difficult conditions and sufferings of other people' and 'acting with deep empathy and kindness towards the marginalized and the excluded people' (Navarro-Castro \& Nario-Galace, 2010). It coincides with the core value of 'love and compassion' of concept of 'learning to be'; the concept of 'compassion' within core value 'peace' of 'learning to live together'(GOP, 2017; B. Johnson, 2001; Vira \& Cordesman, 2011)

Talking about how the secondary schools endeavour to develop a 'compassionate attitude' among their students, the education managers $(f=34)$ affirmed that the students are taught about it by quoting Quranic Ayats and sayings of Holy Prophet (莎). Most of the Head Teachers reported that during teaching 'Islmic Studies', 'Urdu' and 'Pakistan Studies', teachers put forth the importance of 'compassion' with reference teachings of Islam and mention examples from صلى ( صل and his pure followers treat the poor and the marginalized; how they were always ready to help the needy people; how they took pity even on animals, birds and insects; and barred his followers not to beat the animals on their faces and not to mark on their backs. Alongside, relevant narrations from the Holy Quran are presented carrying the reward for those in the hereafter who are compassionate to others. Moreover, pertinent incidents from our national history are related e.g. the sacrifices of their elders for their brothers in the catastrophic times of partition in 1947; the long queues of blood donors in the war of 1965; the rehabilitation efforts during disastrous flood in 1992, during earthquake on $8^{\text {th }}$ October, 2005, and the record support to welfare organizations like 'Edhi' and the others. 
Data also revealed that in schools, teachers themselves support the needy students from their pocket and from school funds thus setting practical examples of 'compassion'.

"There is a 'Charity Committee' in our school. A senior teacher as chairman and class prefects constitutes the committee. The chairman in consultation with members identifies the deserving students and tries to solve their financial problems. In this way we practically promote compassion among students". (Respondent-38: Head Teacher)

\section{Theme-6: Global Concern}

'Global concern' refers to 'caring for the whole human community transcending beyond one's concerns for his/her national, local/ethnic (e.g., religious, cultural) community'. This theme corresponds with the theme of 'interdependence' and 'national unity and global solidarity' in 'learning to be' supported by UNESCO (GOP, 2017; B. Johnson, 2001; UNESCO, 1998). This value and its subsidiary themes have been ranked as highly important to teach for developing 'global concern' among students (UNESCO, 1998).

Majority of the education managers $(f=24)$ authenticated that secondary schools partially promote the sense of 'global concern' in their students. They very enthusiastically try to teach the 'caring for whole human community' but were found reluctant to ignore their religious, local, national and cultural concerns in the face of global concern. It was further supported by the content in the textbooks (e.g., Pakistan Studies) that contain material on adverse foreign relations with India, particularly on Kashmir issue and China Pakistan Economic Corridor (CPEC), and so-called conspiracy by the West against the progress and solidarity of Pakistan. Furthermore, the countries which suppress and destabilize the Muslim countries are not favoured under the ideology of Islamic solidarity (e.g., America and Israel). The education managers declared that they teach their students 'Respect for religious and cultural traditions of others but unluckily same attitude is not shown by the opponents'.

"No nation can compromise on their national interests and religious concerns and so we are." (Respondent-37: Head Teacher)

It was also evident that students from other religions or religious sects are allowed to celebrate their festivals and share their feelings freely. Students are taught about the human solidarity and natural oneness as supported by Islamic teachings.

"Some of our schools are connected with British Council. Global social issues are shared with students of other education institutions to broaden their vision about global community. They are trained to develop their behaviour as a useful global citizen." (Respondent-21: CEO)

صلى الله (We inform our students about the agreement of Holy Prophet Muhammad

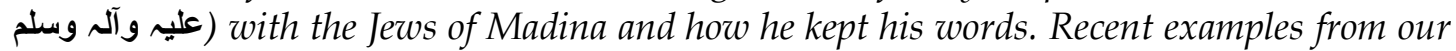
Pakistani culture are also mentioned; how Hindus, Christians, Sikhs and other minorities are 
living here peacefully. Their religious places and festivals are protected by the government and our constitution grants this right to them" (Respondent-26: Head Teacher)

"Moreover, students celebrate 'Earth Day', 'Mother Day' and other days along with other children over the globe. It promotes a sense of human solidarity among them and they feel themselves as a member of a global family." (Respondent-11: CEO)

\section{Theme-7: Ecological Concern}

For this study, 'ecological concern' refers to 'caring for the natural environment and preference for sustainable living and simple life style' (NavarroCastro \& Nario-Galace, 2010). These concepts are very important to be taught to students as they have been recommended by UNESCO in its key document 'Learning to Live together' as essential themes i.e. 'environmental concern', 'stewardship of resources', 'simplicity' and 'personal ecology' of the fourth core peace value 'sustainable development' (GOP, 2017). Hence, this is inevitable to teach these themes to students.

Education managers were interviewed to grasp the peace teaching practices in secondary schools of the Punjab with reference to 'ecological concern'. Majority of education managers $(f=35)$ affirmed that 'ecological concern' is tried to instil in the minds of students. They viewed that students are educated about 'caring for their natural environment'. They are sensitized to the benefits of keeping themselves and their environment clean; the positive impact of tree plantation; and efficient use of natural resources. Alongside, they are acquainted with the devastative implications of 'deforestation' and wastage/excessive use of natural resources.

Respondent-6 (Head Teacher) stated:

"In our school, competition among students is organized titled 'The Clean Classroom' and 'The Green School'. The students, who bring or make the most beautiful dust bin are awarded with a prize. Similarly, the concerned teachers daily check cleanliness of body and uniform of their classes. Moreover, we launch tree plantation campaign twice a year and students play their active role in it."

"The advantages of living a simple life are taught to students during regular classroom teaching complemented by the Quranic commandments and examples from the life of Holy Prophet (\$) and from real life local examples." (Respondet-27: Head Teacher)

"International days e.g., Earth Day, Environmental Care Day etc are celebrated, although symbolically, in the schools to make them aware of the significance of 'environmental concern'". (Respondent-32: DEO)

\section{Theme-8: Cooperation}

The peace value of 'cooperation' refers to 'valuing the principle of working together towards the pursuit of common goals' (Navarro-Castro \& Nario-Galace, 
2010). This peace value is consistent with the concept of 'Learning to Live together sustainably' promulgated by UNESCO (GOP, 2017; Loh, Chew, Leong, Tan, \& Yan, 2014). This peace value is inevitable for peaceful coexistence in all walks of life (Balasooriya, 2001)vital to be developed as an attitude among the students.

Most of education managers $(f=36)$ supported that the schools try to cultivate the peace value 'cooperation' in the minds of their students. They stated that during co-curricular activities students have to work in a group with other fellows whereby they learn the worth of different processes that are used to complete a task within a group.

"They learn the importance of various cooperative techniques through learning by doing" (Respondent-17: Head Teacher)

"While playing in a team. They do collective efforts to achieve a common goalwinning the match as a team. It helps them promote the sense of cooperation among students." (Respondent-29: Head Teacher)

The respondents also stated that the students enjoy the opportunity to work as team member while group study activity; discussion session; inter class competitions and as a team member the during sports competitions.

"We arrange inter-class competition for decorating classrooms. The students of a class work together to beautify their classrooms: they clean the classroom together; prepare charts and models, decoration items in groups." (Respondent-14: Head Teacher)

\section{Theme-9: Openness and Tolerance}

'Openness and tolerance' means having openness to the processes of change; showing willingness to approach and receive other people's ideas, beliefs and experiences with a critical but open mind; and respecting the rich diversity of world's spiritual traditions, cultures and forms of expressions' (Navarro-Castro \& Nario-Galace, 2010). The concept of 'openness and tolerance' has gained the acceptance and support by world's highest ranked organizations e.g., UNESCO and UNICEF (Vira \& Cordesman, 2011).

A large number $(f=28)$ of the head teachers opined that the peace value 'openness and tolerance' is not properly instilled in the minds of students.

"The world is changing very fast. It is the time to prepare our students for accepting the challenge of 'change' instead of resisting it. They also need to make their minds for keeping pace with the speedy growth of the world. Unluckily, our education system is unable to address this issue and teachers are not ready for it, by some reason or the other, to make serious efforts at their own level." (Respondent-22: DEO)

Results of the data also show that, in respondents' views, $(f=30)$ one of the major causes for unrest in the society is that we, as a nation, particularly our present 
generation is not found willing to receive and apprehend the other people's ideas, beliefs and experiences with open mind.

"It is commonplace in our society to criticize or discuss in a negative way, the culture, beliefs and experiences of other people specifically which are associated with certain casts or professions. Students and teachers too come from this type of cultural background. They do not discourage this practice. So, the students informally learn this abuse from their fellows." (Respondent-32: DEO)

On the other hand, some of the respondents $(f=08)$ opined that the 'open' and 'tolerant' attitude is promoted in students during regular teaching learning activities.

"The books of Urdu, Islamic Studies and Pakistan Studies contain relevant material on the importance of tolerance. There are a lot of incidents in our history that show how the Muslims were tolerant towards other communities. These examples are narrated by the teachers during teaching." (Respondent-17: Head Teacher)

\section{Theme-10: Justice}

The peace value 'justice' operationally refers to 'acting with a sense of fairness towards others (fair dealing); upholding the principle of equality in dignity and rights of other people; and rejection of all forms of exploitation and oppression' (Navarro-Castro \& Nario-Galace, 2010).

The peace value 'justice' corresponds with the theme of 'equality and justice' included in 'Learning to Live together'. It is integral to educate our students about its necessity to make them able for a global peaceful citizen (GOP, 2017; Vira \& Cordesman, 2011). Article 37 (d) \& (e) of the Constitution of Islamic Republic of Pakistan stresses upon provision of justice and ensuring just and human conditions of work particularly for children and women (GOP, 2012).

During their interviews the majority of education managers $(f=30)$ claimed that the concept of 'justice' is taught to students in various ways within schools. For instance, to persuade the students for 'fair dealing with others', teachers narrate examples from the life of Holy Prophet Muhammad (․ supported by the Ayaats from the Holy Quran.

"Holy Prophet Muhammad (") is the role model for a Muslim. During classroom teaching, students are urged to follow how fairly he dealt with others even with his enemies." (Respondent-40: Head Teacher)

"We have developed a culture of mutual respect and caring for the dignity of others including students based on equality and justice in our school. A three member committee settles the disputes among staff as well as students in a just way. I feel they are doing well." (Respondent-35: Head Teacher) 
Data also indicated that in most of schools there are discipline committees which are responsible to maintain discipline and order in the schools. The committees are meant for the cessation of any type of violence and exploitation against any student.

"No one in the school premises is allowed to threat others in any way. We try to provide them best possible security assurance. I have zero tolerance against favouritism and oppression" (Respondent-04: Head Teacher)

\section{Theme-11: Social Responsibility}

'Social Responsibility' is referred to as 'willingness to contribute in shaping a society characterized by justice, nonviolence and well-being of the people; sense of responsibility towards present and future generation'. Social responsibility is defined as the voluntarily adopted obligation of an individual to work for the wellbeing of the society. It resembles with the having sense of 'stewardship of resources' for common good. It is conceived as acting in a way consistent with the values and norms of the society, and working to secure the future of coming generations (Vaismoradi, Turunen, \& Bondas, 2013).

Results of the data depicted that maximum number of the respondents $(f=28)$ opined that the services rendered secondary schools to promote the sense of 'social responsibility' are not at par with national and international demands. There is a lack of vision among teachers in this regard. Most of them do not have proper apprehension of the need and significance of this issue. They are not desirably seemed willing to take the responsibility of transforming their pupils in a socially responsible citizen. Consequently, our schools are lagging behind in producing a socially responsible next generation.

"Most of the teachers are unaware of the challenges of $21^{\text {st }}$ century. They do not have, in most of cases, any orientation about their social responsibilities. They do not bother to think out of the box." (Respondent-31: CEO)

"Well, our teacher community might be wishing to play their part for a just, nonviolent and a welfare society but I fear no one is ready to owe the responsibility with some exceptions." (Respondent-22: DEO)

"Students are motivated to participate in certain events like Meena Bazar (in girls' secondary schools). During these events students are assigned different jobs which they have to perform on their own voluntarily for their group. In this way, they learn how to work as a responsible person". (Respondent-26: Head Teacher)

"Students are educated about the significance of working for common good of the society. And yes, we have several examples to quote from within our country like Abdus Sattar Edhi, Dr Ruth Faw and more importantly our historical heroes like Quad e Azam, Allama Iqbal etc. who devoted their lives for the future of their nation." (Respondent-19: Head Teacher) 


\section{Theme-12: Positive Vision}

'Positive Vision' is conceived as 'imaging the (peaceful and sustainable) future with a sense of hope; and pursuing its realization by all possible ways' (Navarro-Castro \& Nario-Galace, 2010). This peace value is also consistent with the concept of 'future orientation' as a sub-theme of 'Learning to Live together' propounded by UNESCO(GOP, 2017; Vira \& Cordesman, 2011).

Data collected through interviews with the education managers highlighted that maximum number of the respondents $(f=21)$ affirmed that the secondary schools partially develop the sense of 'Positive Vision' among students. It was found from their views that the sense of thinking optimistically about their imagined future is developed but they are not properly guided on how and by which suitable means they will be able to achieve their goal. Lack of competence, training and exposure were identified as potential causes on the part of teachers.

"There is sufficient content on positive vision specifically in 'Pakistan Studies' textbooks. The vision of Quaid e Azam for a separate homeland of Indian Muslims and his struggle for its achievement is a golden example to present before the students. Students are educated to set high goals in life and strive to achieve by putting their full potential like Quaid e Azam." (Respondent-15: Head Teacher)

"We inherent a very rich history of visionary people who not only succeeded in attaining their goals but also left long lasting impression over the world. There marvellous accomplishments are used as reference to promote the ability of positive vision among students." (Respondent-27: Head Teacher)

"Obviously, teachers try to educate their students about it but there is no practicum in the curriculum to develop the ability of imaging positively. I think this is a skill, this is an art. It needs practice rather than just getting informed about it." (Respondent-05: Head Teacher)

"In my opinion, we lack in two areas in this regard. Firstly, no proper content and teaching methodology is provided in the curriculum for this purpose. Secondly, our teachers are not duly trained to address this issue and the others like this one." (Respondent-21: CEO)

"There is no such mechanism at secondary school level to guide their students about planning their future. None of the teachers counsel them how to realize their dreams in life. What are the opportunities for them and what potential challenges they might have to face. They feel themselves helpless." (Respondent-22: DEO)

\section{Discussion}

It was a matter of great concern that 'gender equality', 'openness and tolerance' and 'social responsibility' were reported to be ignored during teaching learning activities in secondary schools. Most of the head teachers opined that the 
peacevalues were not prioritised during regular teaching because they were not the part of the formal curriculum. Similar findings were reported by Harber and Sakade (2009) who conducted a case study to see the principles and practices carried out by West Midlands Quaker Peace Education Project (WMQPEP) in a state urban primary school. Peace education practices, being carried out in secondary schools, were confined to just verbally delivering some information to the students. Seemingly, the underlying aim was not to make them a peaceful citizen but just to meet the urgent requirements of their lessons. Peace education was an absurd concept for most of the respondents. Surprisingly, some of the DEOs and CEOs too were not adequately aware of these concepts before their interviews. For some others it was not an attractive idea to discuss or reflect upon; it was just wastage of time and energy. These non-professional behaviour patterns of the teachers might be the depiction of out-dated system of teacher education which is not compatible with the modern age demands (Khan, 2015; UNESCO, 2006). The findings of the interviews with education managers also supported it who stated that the teachers were not duly trained during 'Induction Training' and 'In-service training' on how to educate their students about these peace values. Teaching these peace values was not a matter of interest for many teachers. They were mostly concerned with preparing their students for getting good marks in the examinations. Same findings were drawn by Afzal (2015). Socio-cultural influence i.e. misconception about certain peace values like 'Gender Equality', 'Respect for Life/Nonviolence' 'Global Concern' and 'Openness and Tolerance', might be another potential cause for the disinterest or avoidance of teaching these peace values by the teachers.

\section{Conclusion}

It was found from the data of interviews with education mangers that all the peace values were not equally focused during teaching learning activities in secondary schools of the Punjab. Secondary school teachers mostly tried to promote 'cooperation', 'self-respect', 'ecological concern' and 'compassion'. The peace values of 'gender equality', 'global concern', 'openness and tolerance' and 'social responsibility' were not duly emphasized during teaching learning activities.

Most of the education managers (i.e., head teachers) reported that the peace values were not prioritised during regular teaching because they were not the compulsory part of the formal curriculum and no particular teaching methods had been recommended for inculcating peace in the minds of the students.

The head teachers also highlighted that most of the teachers were allegedly interested in preparing their students for getting good marks in the examinations instead of making them a peaceful citizen. They further added that the teachers were not duly trained for the very purpose. These findings allowed to conclude that the peace values 'gender equality', 'global concern', 'openness and tolerance' and 'social responsibility' are not duly focused during teaching learning activities in secondary schools of the Punjab. It might be due to the reason that the teachers are not duly trained for the very purpose; they do not take interest in promoting peaceable 
attitudes among students because there is no mechanism to assess the effective domain of students' learning in the assessment system. 


\section{References}

Afzal, M. (2015). Education and Attitudes in Pakistan: Understanding Perceptions of Terrorism. Special Report 367: ERIC.

Ali, I. (2015, December 19). Four Well-educated Men held on Terrorism Charge. $D A W N$. Ardizzone, L. (2001). Towards global understanding: The transformative role of peace education. Current issues in comparative education, 4(1), 1-10.

Aree, S.-A. (2011). Developing a model of peace education in the undergraduate teacher training process for early childhood education at Rajabhat Universities, Thailand. Northumbria University.

Atran, S. (2003). Genesis of suicide terrorism. Science, 299(5612), 1534-1539.

Balasooriya, A. (2001). Learning the way of peace: A teachers' guide to peace education.New Delhi: United Nations Educational, Scientific and Cultural Organization.

Berrebi, C. (2007). Evidence about the Link Between Education, Poverty and Terrorism among Palestinians. Peace Economics, Peace Science and Public Policy, 13(1), 1-38.

Best, J. W., \& Kahn, J. V. (2006). Research in education, 10th. New Delhi: PHI Learning Private Ltd.

Castro, L. N., \& Galace, J. N. (2010). Peace Education: A pathway to a culture of peace. Quezon City: Center for Peace Education.

Cohen, L., Manion, L., \& Morrison, K. (2013). Research methods in education (7th ed.): Routledge.

Craig, E. (2005). The shorter routledge encyclopedia of philosophy: Routledge.

Creswell, J. W. (2013). Research design: Qualitative, quantitative, and mixed methods approaches: Sage publications.

Davies, L. (2013). Education, Change and Peacebuilding. Bonn: Fri Ent, Working Group on Peace and Development.

Emah, Ime Effiong, E. Etudor-Eyo, U. D. Akpanumoh, E. G. Akpan, and W. I. Jude. "Peace Education and Gender Equity among Nigerian South-South Youths." Educational Research Network for West and Central Africa (2008).

Fountain, S. (1999). Peace education in UNICEF: Unicef, Programme Division.

Fraenkel, J. R., Wallen, N. E., \& Hyun, H. H. (2012). How to design and evaluate research in education (Vol. 7): McGraw-Hill New York. 
Fraenkel, J. R., Wallen, N. E., \& Hyun, H. H. (2015). How to Design and Evaluate Research in Education. New York, USA: Mc Graw Hill.

GOP. (2009). National Education Policy. Islamabad: Ministry of Education, Government of Pakistan

GOP. (2012). The Constitution of the Islamic Republic of Pakistan. Islamabad, Pakistan: National Assembly.

GOP. (2017). National Education Policy 2017-2025. Islamabad, Pakistan: Ministry of Federal Education and Professional Training Government of Pakistan

Harber, C., \& Sakade, N. (2009). Schooling for violence and peace: how does peace education differ from 'normal'schooling? Journal of peace education, 6(2), 171-187.

Johnson, B. (2001). Toward a new classification of nonexperimental quantitative research. Educational Researcher, 30(2), 3-13.

Johnson, D. W., \& Johnson, R. T. (2010). Peace Education in the Classroom: Creating Effective Peace Education Programs. In G. Salomon \& E. Cairns (Eds.), Handbook on peace education (pp. 223-240). Psychology Press.

Khalid, S. (2013). A Study Of Developing Tolerance Among Prospective Teachers Through Classroom Activities. University of the Punjab, Lahore.

Khan, W. (2015). Quality of Teacher Education in Pakistan. Dialogue, 10(2), 213.

Krueger, A. B., \& Malečková, J. (2003). Education, poverty and terrorism: Is there a causal connection? The Journal of Economic Perspectives, 17(4), 119-144.

Loh, C. C., Chew, C. C., Leong, W. L., Tan, T. C., \& Yan, W. Y. (2014). A study on factors influencing students" intention to pursue higher education. UTAR.

Navarro-Castro, L., \& Nario-Galace, J. (2010). Peace education: a pathways to a culture of peace. Miriam College, Quezone City, Philippines: Centre for Peace Education.

Tanabe, J. (2014). Buddhism and Non-Violent World: Examining a Buddhist Contribution to Promoting the Principle of Non-Violence and a Culture of Peace. Philosophy East and West, 52(3), 326-345.

Ty, R. R. (2011). Human rights, conflict transformation, and peace building: The state, NGOs, social movements, and civil society-The struggle for power, social justice and social change: Northern Illinois University.

UNESCO. (1998). Learning To Live Together In Peace And Harmony: Values Education for Peace, Human Rights, Democracy and Sustainable Development for the Asia-Pecific 
Region. Bangkok, Thailand: UNESCO Principal Regional Office for Asia and the Pacific.

UNESCO. (2006). Situation Analysis of Teacher Education in Pakistan: Towards a Strategic Framework for Teacher Eucation and Professional Development Islamabad: UNESCO/USAID.

Vaismoradi, M., Turunen, H., \& Bondas, T. (2013). Content analysis and thematic analysis: Implications for conducting a qualitative descriptive study. Nursing $\mathcal{E}$ health sciences, 15(3), 398-405.

Vira, V., \& Cordesman, A. H. (2011). Pakistan: Violence VS. Stability. A national net assessment. Washington: CSIS. 